\title{
"Elsa, Why are you in Fear and Anger?": The Power of Magic and Control of Emotion in Frozen
}

\author{
Eun Jung Park*
}

\begin{abstract}
This paper has the first aim to analyze Elsa's magic power of why and how she, as a heroine in the animation of Frozen, is in the emotion of fear and anger. This paper will explain why these two emotions are twisted compound to identify Elsa's iced emotion in the ice kingdom. And secondly, this paper attempts to connect Elsa's fear emotion in her real life is the other flip with that of anger throughout the characters' network in Frozen, which symbolically reflect the feminine pattern of real society that Walt Disney prospects for the dream society. Through the cognitive process for Elsa's ice kingdom between emotion status and social network, we can assume the pattern of social network with emotional chart and the archetype of human emotion through the cognitive-emotional storytelling on the emotion of Elsa in Frozen.
\end{abstract}

Keywords : Frozen, Disney animation, emotion of fear and anger, affective interaction, Elsa

\section{“엘사여, 뭐가 그리 두렵고 분한가?": 『겨울왕국』에서의 마술의 힘과 감정의 통제}

\author{
박은정*
}

요 약

본 논문은 디즈니 만화영화 『겨울왕국』에서 특이한 마술적 힘을 가지고 있는 엘사를 주인공으로 놓고, 그녀가 왜 두려움과 분노의 감정을 가지게 되었고 이런 감정을 어떻게 마술로 표출하는 지를 분 석하는 것을 일차적 목표로 정한다. 마술을 걸기만 하고 풀지 못하는 자유롭지 못한 엘사가 자신의 왕 국을 떠나가는 것이 그녀의 두려움과 분노에 찬 얼어붙은 왜곡된 감성을 스스로 얼음성에 갇히게 만드 는 상징적 행위로 해석한다. 둘째로는 디즈니의 여성성에 대한 새로운 양상을 보여주는 본 『겨울왕 국』은 환상적 애니메이션이 실제 사회의 여성적 억압에 대한 분노와 그 두려운 해방감에 관한 문제해 결과 얼마나 유사한 패턴을 가지고 있는 지를 시청자가 엘사와의 감정이입을 통한 감정 상호작용을 통 해 분석하고자 한다. 마지막으로 본 논문은 스토리텔링 기법을 통해서 엘사를 중심으로 시청자의 두려 움이나 분노가 어떤, 그리고 얼마나 증폭적인 감정 상호작용을 함으로써, 인간 보편적인 분노와 두려움 의 감성인 엘사의 감성이 어디서 근원되었고, 왜 마술로 독특하게 상징적 재현이 되며, 그 감성을 어떻 게 해결하는 지의 과정을 독자와의 스토리텔링 상호작용을 통해서 분석한다.

키워드 : 『겨울왕국」, 디즈니 만화영화, 두려움과 분노의 감정, 감정 상호작용, 엘사

\section{Introduction}

※ Corresponding Author : Eun Jung Park

Received : December 11, 2016

Revised : December 26, 2016

Accepted: Decembe 31, 2016

* Minerva Liberal Arts College Hankuk University of Foreign Studies

Tel: +82-2-2173-2121,

email: eunjp@hufs.ac.kr
Disney animation, Frozen(2013)[1], loosely based on Hans Christian Andersen's The Snow Queen (1844), tells the story of two sisters,

- This research was financially supported by Korea Research Foundation. (NRF-2014S1A5A2A01017353) 
Elsa and Anna, the former of which was born with magical powers to create ice and snow. Haunted by the moment that her magic nearly killed her younger sister, Elsa is encouraged to isolate herself in a submission to suppress her apparently dangerous powers. Due to her weird magic power, Elsa was afraid. Due to her emotional intensity like fear and angry, she makes anything which is touched by her body into frozen ice. It is her unique fate that she is trapped within the power of magic.

This paper will study the emotions in Frozen to diagnose the true reason for fear and anger which is dominant in the mind of Elsa. Comparing specific Disney roles between men and women, Elsa's emotion seems different due to her power of magic. This paper exploits that Disney has made changes in their films by removing some overt gender stereotypes from Frozen; however, they continue to use many of these stereotypical gender expectations.

Frozen has developed the characters' emotion of love between Anna and Elsa by acquiring sisterhood from their childhood, and female characteristics in the palace as princesses, but encouraging Elsa with independency as a successor of the kingdom. Stephanie Merry, a writer for The Washington Post, represents the majority opinion on why Princess Anna is seen as the modern princess: "Anna is much more of a contemporary heroine .... she's no damsel in distress, not even during the film's late scenes, when she finds herself in a desperate situation"[2]. I partially agree Merry's analysis to put Anna heroine owing to her exodus and her sacrifice to prevent Prince Han's devil-like sword from Elsa.

However, this paper would rather focus on Elsa's femininity, her emotions such as fear, anger, and love, and the desire to express her unfettered emotions biased male dominant society, that is, under the protection by her father's, and the King's authority, which paralyses Elsa's emotional development of natural expressions. Under the conduct of over-protection by the Arendelle's king and her father, Elsa can never show her naturally spontaneous emotions and then cell herself due to the fear of magic power beyond her control. She makes herself criticize and restrict with no appealing her spontaneous emotions. Only with fear and anger toward her cursed magic, Elsa can neither show her emotions nor express her prison-like femininity. Elsa must hide to express her free emotion and veil her magic power as well desperately. She attempts to freeze her emotions and make her emotions frozen through the psychological depression twisted by her father, the absolute power, so called.

What if Elsa could express her emotions spontaneously with her talented and powerful magic? What if Elsa could exert her magic power thoroughly? What if her magic could possibly cause the world more beautiful, healthier, and more efficiently paralleled with her freely blossomed emotions? Because the ice and snow, into which Elsa can make all the things turn, are necessary in our life, when the world gets balanced. Elsa should learn how to control her emotions through the sophistication to make her magic get balanced.

This paper would explore Elsa's frozen emotion with 'fear and anger', which are empathizing to the viewers' hearts when they are watching the film of Frozen. Since Elsa then come to grow a female leader of Arendelle, the viewer firstly focus on her as an independent and strong minded character. However, some of her actions as well as phrases she is about to say, touch the viewer's mind by realizing that Elsa's mind not only can be the equivalent of piling up the frozen desire like the frozen, but also can contain a strong sense of responsibility as a princess. 


\section{Elsa, why are you afraid and in anger?}

King of Arendelle, her father used to say to his daughter, Elsa, "no feeling" to protect her. As a young princess, Elsa confesses that how much she has been beard to conceal her feeling, she now shouted, "Heaven knows I tried. $\cdots$ The wind is howling like this swirling storm inside." Elsa's monologue song, "Let it go, in Real Life" is so powerful to attract viewers. The song of "Let it go" is too adventurous for a little beautiful Elsa to stand by herself. However, right after the shouting her emotional confession, "Let it go in Real Life", Elsa goes to her own ice kingdom, where is lonely, but as powerful and great as it is. According to the confessional song of "Let it go", we can assume that Elsa has been just listening to her father to "be the good girl", because she 'always has to be.' She is now isolated in the ice kingdom where everybody believes her to be the perfect queen. However, people are neither allowed to peep into her true psychology nor to see her real situation, which makes Elsa feel unfettered and even comfortable away from everybody. Afraid of hurting Anna again, and with her ability to control her powers deteriorating, Elsa spends most of her time alone in her room, refusing even to speak to Anna and a snowman created by themselves as they grow up.

Despite Elsa's fears, her coronation barely takes place without incident. During the reception, however, two sisters begin to argue, culminating in the exposure of Elsa's disabilities in an emotional outburst. Due to Anna's too easily falling in Love with prince Hans("Love is An Open Door"), Elsa cannot understand Anna's appeal to her marriage. Elsa portrays several physically and verbally aggressive traits because of her oppositional concepts on love and marriage. Elsa repressed her feeling of love toward Anna in order to protect Anna away from her own magic. Love is not an open door for Elsa toward Anna because of her own magic, which can possibly hurt Anna. Elsa looses to control her emotion, and, at last, legitimize her magic power by her mistake. All the people of Arendelle are shocked. Elsa is extremely embarrassed to finally recognize that no way to veiling her magic.

The recurring statement in the song of "Let it $\mathrm{gO}^{-}$in Real Life" represents Elsa's psychology that her father has reinforced Elsa these hegemonic portrayals: "conceal- don't feel". This phrase is repeated throughout this monologue song, while Elsa ventures out to the ice mountain after getting out of the coronate procedure. She totally recalls that the words of "conceal-don't feel" was first heard by Elsa's father when she was a child as he gave her gloves to protect and hide her magic powers. This statement from Elsa's father reiterates to inscribe Elsa's conscious and unconscious mind cognition. Owing to her magic power, Elsa should "conceal- don't feel". So Elsa has an ultimate fate to hide her emotion through no touching, and to prevent feeling from her body. Disney intends not to reveal young Elsa's mind, which is supposed to block her emotions physically or violently instead of emotionally[3]. Disney rather focuses Anna's heart concerning what and how to response to Elsa's abrupt segregation, instead. Elsa is not supposed to show her emotions and that is clearly what Elsa's father has taught her to do as well. Aside from Elsa's portraying stoic characteristics in her lonely cell, she also acts violently in the film when she does show her emotions with anger.

Elsa's fear is turning into the anger. Frozen has popularly been debated as likened the construction and treatment of Elsa to cultural 
responses to mental illness, because of father's request to be a perfect girl. Elsa's narrative song in particular, tended to focus on the concept of the 'perfect girl', which is articulated explicitly in the lyrics of 'Let it Go':

... A kingdom of isolation and it looks like I'm the queen

The wind is howling like this swirling storm inside.

Couldn't keep it in, Heaven knows I tried.

Don't let them in, don't let them see.

Be the good girl you always have to be.

Conceal, don't feel, don't let them know.

Well, now they know!

Let it go, let it go!

Can't hold it back any more.

Let it go, let it go!

Turn away and slam the door.

I don't care what they're going to say.

Let the storm rage on.

The cold never bothered me anyway.

$\cdots$ And the fears that once controlled me, can't get to me at all

It's time to see what I can do, *

to test the limits and break through.

No right, no wrong, no rules for me.

I'm free!

.. My power flurries through the air into the ground.

My soul is spiraling in frozen fractals all around

And one thought crystallizes like an icy blast

I'm never going back; the past is in the past!

Let it go, let it go.

... That perfect girl is gone

Here I stand, in the light of day.

Let the storm rage on! [4]

The cold never bothered Elsa anyway. It is because her fear is turning into the anger. The extent to which the reference to the 'perfect girl' was a key trigger for Elsa to implicit her mental illness. She's always suppressing her desires to be "the good girl she always has to be" and is like a control freak. She has a really strong sense of guilty and responsibility and because of her magic power, she withdraws from her sister and from everyone else, afraid that her own feelings could hurt them, she was intentionally like "NO SENSE!". Being the perfect girl all the time and hiding the struggles she is in suffer to make everyone else happy.

The idea of being the 'perfect' girl who simply wants to 'make everyone else happy' resonates with what was once a white middle-class girl who is living up to parental expectations. Such a stereotype emerged in the post-war period in both Britain and America, $[5,6]$ and was indicative of the conception of 'mental illness', often locating what was seen to be in 'faulty' suburban, middle-class families.

Given the extent to which Frozen has popularly been debated as more 'feminist' than its predecessors, Elsa's later refusal to be the 'perfect girl' - an identity that is defiantly cast off as she absconds to the ice kingdom may make sense in terms of the animation's relationship with previous Disney princess ones. A key focus in the feminist scholarship has been their diachronic evolution: how, why and to what extent the Disney princess has changed over time in relation to the shifting rhythms of gender politics[7,8]. Perspectives differ in this regard, although there is some agreement with the suggestion that "heroine of sorts has both a voice and a desire for adventure'[9]. This was in comparison with the previous representations of the Disney princess, such as Snow White, Cinderella or Sleeping Beauty, who were 'simply gentle, kind and lovely', what Jill Birnie Henke et al notably conceptualize as the 'perfect girl'[10].

This has explored such problems in relation to the socially constructed nature of female identity. The role of the media in perpetuating 'idealized images of thinness as beauty'[11] was recognized here. The visual and narrative construction of femininity in the animation of Frozen, is represented towards the contemporary audience who needs to see a strong female leadership by standing along with their male counterparts. By doing so, Disney encourages the idea of equality 
between genders and helps build a universal acceptance of the concept of defining oneself not by how one is born, but by his or her own actions.

Elsa as a female princess is particularly muted by her father and has to "choose her words carefully in order to be successful in the male-dominated public arena"[12]. Elsa has been the actual silence of speech, but rather expresses how women are unable to speak when and where they desire without being interrupted by the male dominancy. Stereotyped silence of Elsa languages can also determine how women should be have since they have been told to stay in their place when male topics are discussed.

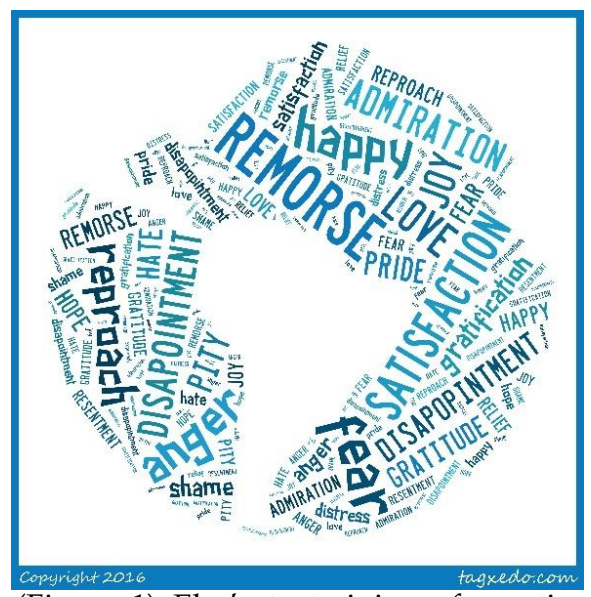

(Figure 1) Elsa's textmining of emotion

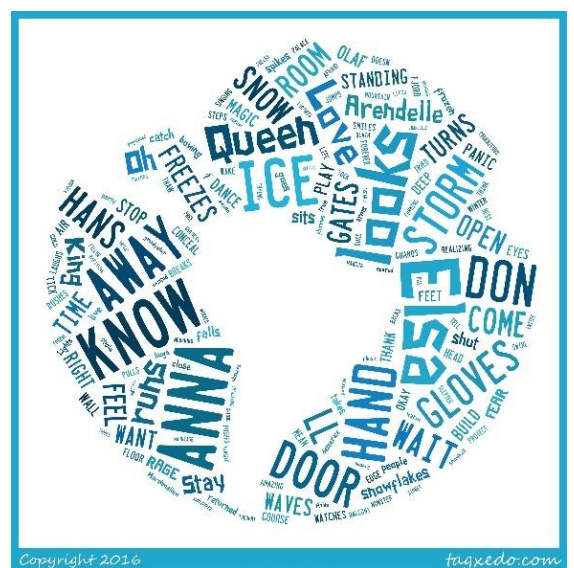

(Figure 2) Elsa's textmining of action
The above (Figure 1) and (Figure 2) are scaled from the text mining according to Elsa's dialogue with Anna and other people as well in order to extract Elsa's emotion and action from the whole script of Frozen. Based on all the script of Frozen concerning Elsa, audience(viewers) emotions are fluctuating.

Emotion, of today, has just started to investigate and measure from various perspectives and across several domains within human computer interaction (HCI) including intelligent tutoring systems, interactive web applications, social media and human-robot interaction. One of the most promising and, nevertheless, challenging applications of affective computing (AC) research is up to computer games. However, this paper rather focuses on the storytelling architecture for the study of emotion in the Disney animation film, Fozen(2013), in which I can diagnose the interactions between the protagonist of Frozen, Elsa and Anna, between Elsa and the other characters from the responses of viewer's emotion.

What is fascinating is that Frozen's viewers willingly engage in an experience that is likely to even involve negative emotions such as fear, anger, and frustration[13]. So, while Disney animation can provide viewers an arena for eliciting, evaluating, expressing and even synthesizing emotions, we argue that one of the primary aims of the study of emotion in watching Frozen is the understanding of viewers' emotions and its link with their experience. Indeed, by the nature of what constitutes a Disney animation, one cannot dissociate this film from emotions. Emotions are not only the trigger for the positive film experiences, but also one of the main targets for negative images. For this purpose, this paper focuses on emotions that can be detected, modelled from, and expressed in Frozen with audiences. 


\section{Viewers' Emotional Research: The Affective Interaction}

Frozen can importantly offer the most meaningful realization of the affective interactions between the protagonist and heroin, Elsa and the viewers. When this paper analyzes the viewers(readers) emotion, it is both entertaining and interacting in that fantasy worlds affect to liberate the limitations of human experience. Frozen is designed to offer affective experiences such as frustrating, anxious, and fearful episodes of Elsa's adventure against her fate of magic omen. Emotional states such as fear and anger, frustration, and anticipation but also cognitive states such as challenge define critical aspects of the viewer's experience which is dependent on the narrative affective interaction. The idea of an affective interaction is involving both body and mind, inseparably, as a basis for design of embodied interactive systems between the characters and readers(viewers).

Within the films, emotions are elicited via stimuli offered during the interaction through viewer's observation. Emotions can then be detected and modelled, assessing the responses of the viewer to the corresponding animated movie stimuli. Such detection can then affect the film responses that may involve emotions expressed in several ways via movie adjustable elements; and finally, film elements such as image, text, and sound, can be adapted dynamically to cater for the current emotional state of the viewers. The affective interactions in Frozen movie can be viewed as comprised of three sequential key phases organized in a closed-affection:

1) the viewers express their emotions through the interaction with a movie;

2) the movie then detects the emotional reactions of the viewer, and interprets those reactions according to the context of the film animation;

3) based on that interaction, Frozen makes adjustments that can be achieved via emotional modelling and expression. This in turn affects the viewer (both his/her mind and body) making him/her respond with emotional reactions.

Emotion detection and emotion modelling in Frozen is going toward the multidisciplinary intersection of the fields of viewers' emotional modelling, experimental psychology and, even up to human-computer interaction as a basis. Emotion detection through films is an area that has provided the recent research studies through the strategy of storytelling architecture.

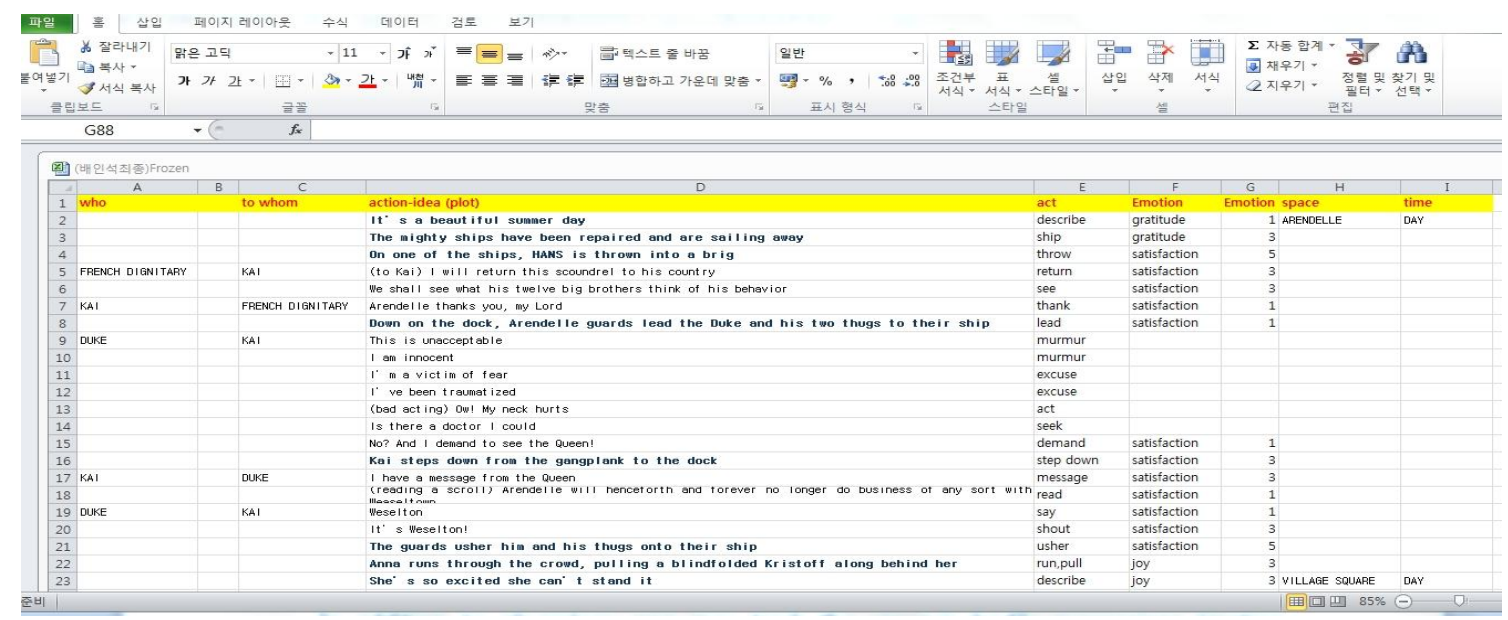

(Figure 3) Frozen tagging \& coding through Emotion 
Even though the literature is rich of theories on emotion, one needs to be cautious with the application of such data based theories through films. Ad-hoc designed emotion models on 'fear and anger' can be an extremely powerful and expressive way of representing emotions of the viewers, those who need to be cross-validated in affective emotion research. On the same basis, cognitive processes may influence emotions; one may infer the viewer's emotional state by analyzing patterns of the interaction and associating viewer's emotions with context variable emotions.

The objective emotion modeling above (Figure 3) of Frozen started to investigated with a number of survey sheet records of the viewers' emotion. There are 25 students who majored in English Literature and Cultural Contents have surveyed to reach the outcome of (Figure I \& 2) in the class of Fall and Spring semesters in 2015-2016. There have been several more studies in the class in order to explore the emotion interplay between the physiological heart fluctuations and reviewer's 5 Likert scale by investigating reviewers' emotions in Apocalypse Now, Shakespeare in Love, Ratatouille, The Godfather, and Frozen movies.

\begin{tabular}{|c|c|c|c|c|}
\hline $\begin{array}{c}\text { stimulus } \\
\text { event }\end{array}$ & cognition & $\begin{array}{c}\text { feeling } \\
\text { state }\end{array}$ & $\begin{array}{c}\text { overt } \\
\text { behavior }\end{array}$ & effect \\
\hline threat & "danger" & fear & escape & safety \\
\hline obstacle & "enemy" & anger & attack & $\begin{array}{c}\text { destroy } \\
\text { obstacle }\end{array}$ \\
\hline
\end{tabular}

(Figure 4) Emotion model of fear and anger

(Figure 4) is the emotion model of fear and anger based on the Plutchik's wheel of emotions. The most direct way to annotate an emotion is to ask the viewers themselves about their movie experience and build a model based on these annotations. However, this direct way may be judged as the subjective emotion annotation, because there must be based on either viewers' free-response after watching or on forced data retrieved through questionnaires. Therefore, this paper adopts the objective emotional model of Plutchik concerning fear and anger. Alternatively, 3 experts or external observers such as one English Literature professor, one cinema critic, and one camera PD are also jointly surveyed to annotate the emotional experience of Frozen at the same time.

The below is two dimensions of emotions[14,15] by focusing on 'fear and anger' in Frozen.

\section{Two Dimensions of Emotion}
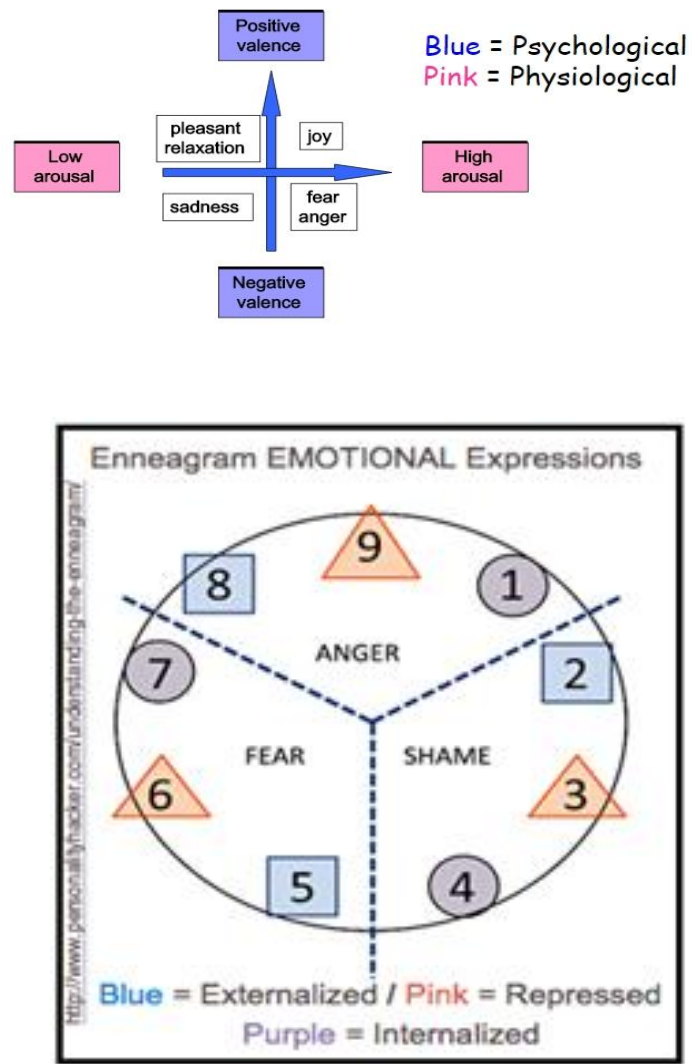

(Figure 5) Emotions of Affective Interaction in Frozen

The above affective interactions are fundamental to persuade viewers to deeply 
engage with Frozen. We have discussed emotion adaptations and emotion expressions, placing it in the context of the emotion fluctuation. The adaptation module of the affective interaction should be able to provide satisfactory answers to, at least some, of the following questions: "which stimulus (or playful experience) should be presented next? When should it be presented? Which film elements should be adjusted and how?" We always keep aware of the emotional flow to find the overall answers which is paralleled with the normal chart of emotion by Paul Ekman[16].

\section{Conclusions: Evaluating Adaptation}

Affective interaction for Disney animation, Frozen leads to personalized experiences for the viewer. A key research question, however, is how do we appropriately evaluate the efficacy of the adaptation mechanism. While several different methods on human emotional research are available, all seem to converge to control-based experiments where films are usually evaluated with and without the emotional evaluation[17].

The outcome of such an experimental protocol usually allows concluding whether adaptation seems to have an impact on the viewer's engagement (or any other relevant emotional state). The efficacy of adaptation can be indirectly measured from standard usability metrics (such as response time), or more directly from the output of the emotional model itself (i.e. testing if adaptation yields higher values for the model's output). In addition, one may perform a viewer survey that asks viewers to evaluate the adaptation experience of protagonist Elsa's emotion.
[1] Frozen http://screenplayexplorer.com/wp-content/s cripts/Frozen.pdf ENDEAVOR TALENT AGENCY 9601 Wilshire Blvd., 3rd Floor Beverly Hills, CA 902 12 Registered WGAw \#1276108 310-248-2000

[2] Merry, Stephanie. Frozen Movie Review: Kristen Bel 1 and Idina Menzel Dazzle in Disney's Latest." Wash ington Post. 26 Nov. 2013.

[3] Towbin, M.A., Haddock, S.A., Zimmerman T.S., Lun d L.K., Tanner, L.R. (2008). "Images of gender, race, age and sexual orientation in Disney feature-length animated films." Journal of Feminist Family Therap y. 15(4): pp. 20-25.

[4] Let it Go Lyrics: http://www.metrolyrics.com/disne ys-frozen-let-it-go-lyrics-idina-menzel.html

[5] Bruch, Hilde. The Golden Cage: The Enigma of Anor exia Nervosa. Cambridge: Harvard University Pres s, 1978. pp. 25-42.

[6] Saukko, Paula. The Anorexic Self: A personal and Political Analysis of a Diagnostic Discourse. Alban y: State University of New York Press, 2008. pp. $2-9$.

[7] Henke, J. Birnie, Smith, Nancy. J, Zimmerman Umbl e, Diane. (1996). "Constructions of the Female Self: Feminist Readings of the Disney Heroine." Women' s Studies in Communication, 19 (2): pp. 229-249.

[8] Stover, Cassandra. (2012). "Damsels and Heroines: The Conundrum of the Post-Feminist Disney Princ ess." A Journal of Transdisciplinary Writing and Re search from Claremont Graduate University, 2, retri eved http://scholarship.claremont.edu/lux/ pp. 2-5.

[9] Stover, Cassandra. (2012). "Damsels and Heroines: The Conundrum of the Post-Feminist Disney Princ ess." A Journal of Transdisciplinary Writing and Re search from Claremont Graduate University, 2, retri eved http://scholarship.claremont.edu/lux/ p. 3.

[10] Henke, J. Birnie, Smith, Nancy. J, Zimmerman Umbl

\section{References}


e, Diane. (1996). "Constructions of the Female Self: Feminist Readings of the Disney Heroine." Women' s Studies in Communication, 19 (2): p. 234.

[11] Malson, Helen. "12 Appearing to disappear: Postmo dern Femininities and self-starved subjectivities." Critical Feminist Approaches to eating dis/orders. edited by Helen Malson and Maree Burns. Sussex: Routledge, 2009. p. 138.

[12] Griffin, E.. A First Look at Communication Theory. (5th ed.). New York: McGraw Hill Companies, 2012. p. 262.

[13] Salen, Katie, and Eric Zimmerman. Rules of Game: Game Design Fundamentals. Cambridge: MIT Pres s, 2003. pp. 302-317.

[14] Gratch, J., \& Marsella, S. (2004). "A domain-indepe ndent framework for modeling emotion." Cognitive Systems Research. 5(4): pp. 269-306.

[15] Conati, C. (2002). "Probabilistic Assessment of Use r's Emotions in Educational Games." Journal of Appl ied Artificial Intelligence, special issue on "Merging Cognition and Affect in HCI”, 16: pp. 555-575.

[16] Ekman, Paul, Wallace V. Friesen, and Phoebe Ellsw orth. Emotion in the human face: Guidelines for rese arch and an integration of findings. New York: Else vier, 2013.

[17] Yannakakis, G. N., \& Hallam, J. "Rating vs. Prefere nce: a comparative study of self-reporting." Affecti ve Computing and Intelligent Interaction. Springer, 2011. p. 437.

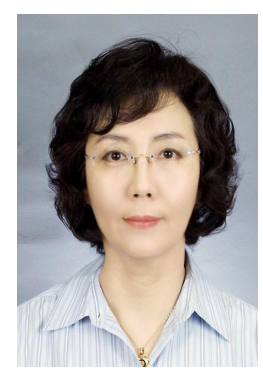

\section{박 은 정}

1984년 2월: 한국외국어대학교 영어과 졸업

1987년 2월: 한국외국어대학교 영어과 미국소설 영문학 석사

1996년 8월: 한국외국어대학교 영어과 미국문화/소설 영 문학박사

1992년 6월 94년 8월 Duke University 객원학자 1998년 2월 2000년 2월 광운대학교 영어영문학과 겸 임교수

2000년 10월 02년 9월 서울대학교 미국학연구소 박사후 연구

2001년 7월 03년 8월 Univ. of Washington 포스 트 탁터/객원교수

2003년 3월 2008년 2월 한국외국어대학교 영미연 구소 연구교수

2001년 3월 02년 2월 부산외국어대학교 강의교수

1987년 3월 현재: 한국외국어대학교 영어과/교양학부 강사

관심분야: 영미문화, 문화콘텐츠, 스토리텔링, 인지 과학, 외국어로서의 한국어 교육 